\title{
Highly specific role of the insulin receptor in breast cancer progression
}

\author{
Ran Rostoker', Sagi Abelson' ${ }^{2}$, Keren Bitton-Worms ${ }^{1}$, Inna Genkin ${ }^{1}$, Sarit Ben-Shmuel', \\ Maria Dakwar', Zila Shen Orr', Avishay Caspi ${ }^{1}$, Maty Tzukerman ${ }^{2}$ and Derek LeRoith ${ }^{1,3}$ \\ ${ }^{1}$ Clinical Research Institute at Rambam (CRIR) and the Faculty of Medicine, Technion, Diabetes and Metabolism \\ Clinical Research Center of Excellence, Haifa, Israel \\ ${ }^{2}$ The Laboratory of Molecular Medicine, Rambam Health Care Campus and Rappaport Faculty of Medicine and \\ Research Institute, Technion, Haifa 31096, Israel \\ ${ }^{3}$ Division of Endocrinology, Diabetes and Bone Diseases, Icahn School of Medicine at Mount Sinai, New York City, \\ New York, USA
}

\author{
Correspondence \\ should be addressed \\ to $D$ LeRoith \\ Email \\ derek.leroith@mssm.edu
}

\begin{abstract}
Accumulating evidence from clinical trials indicates that specific targeting of the IGF1 receptor (IGF1R) is not efficient as an anti-breast cancer treatment. One possible reason is that the mitogenic signals from the insulin receptor (IR) can be processed independently or as compensation to inhibition of the IGF1R. In this study, we highlight the role of the IR in mediating breast tumor progression in both WT mice and a hyperinsulinemic MKR mouse model by induction of $/ r$ (Insr) or Igf1r knockdown (KD) in the mammary carcinoma Mvt-1 cell line. By using the specific IR antagonist-S961, we demonstrated that Igf1r-KD induces elevated responses by the IR to IGF1. On the other hand, Ir-KD cells generated significantly smaller tumors in the mammary fat pads of both WT and MKR mice, as opposed to control cells, whereas the Igf1r-KD cells did not. The tumorigenic effects of insulin on the Mvt-1 cells were also demonstrated using microarray analysis, which indicates alteration of genes and signaling pathways involved in proliferation, the cell cycle, and apoptosis following insulin stimulation. In addition, the correlation between IR and the potential prognostic marker for aggressive breast cancer, CD24, was examined in the Ir-KD cells. Fluorescence-activated cell sorting (FACS) analysis revealed more than $60 \%$ reduction in CD24 expression in the $/ r-K D$ cells when compared with the control cells. Our results also indicate that CD24-expressing cells can restore, at least in part, the tumorigenic capacity of Ir-KD cells. Taken together, our results highlight the mitogenic role of the IR in mammary tumor progression with a direct link to CD24 expression.
\end{abstract}

\author{
Key Words \\ - hyperinsulinemia \\ - insulin receptor \\ - insulin-like growth factor 1 \\ receptor \\ - breast cancer and CD24
}

Endocrine-Related Cancer (2015) 22, 145-157

\section{Introduction}

High levels of circulating insulin were demonstrated to be an important marker and/or mediator of greater breast cancer risk in type 2 diabetes mellitus (T2DM) patients (Peairs et al. 2011). Emerging evidence from follow-up and meta-analysis studies indicates that hyperinsulinemia is associated with a worse prognosis in women with breast cancer even in the absence of diabetes (Goodwin et al. 2002, Belardi et al. 2013). The action of insulin is normally processed through the insulin receptor (IR), but at supraphysiological concentrations, insulin can also activate the insulin-like growth factor 1 receptor (IGF1R). Given the fact that both receptors belong to the same tyrosine kinase receptor subfamily, IR shares great structural homology with the IGF1R especially in the tyrosine kinase domain. In addition, both receptors activate similar signaling pathways, the PI3K/Akt and the

Published by Bioscientifica Ltd 
MAPK pathways (Avruch 1998, Gallagher \& LeRoith 2010), which regulate processes such as cell proliferation, cell division, migration, and apoptosis (de la Monte \& Wands 2005). Both the IGF1 and IRs are frequently overexpressed in breast cancer. Importantly, high levels of expression of the IR (INSR) was found to be associated with decreased disease-free survival in node-negative breast cancer patients (Belfiore et al. 1996, Mathieu et al. 1997). Furthermore, results have indicated that the ratio of IR subtypes (IR-A being more mitogenic than IR-B) may be associated with a worse prognosis; at present, the subtypes are measurable by mRNA levels only (Belfiore et al. 2009, Rowzee et al. 2009, Huang et al. 2011). Investigators have also proposed that IGF1R:IR hybrid receptors may be important in cancer growth; however, their levels are usually much lower than those of holoIGF1R and IRs and they primarily respond to IGF1 (Gallagher \& LeRoith 2010). Thus, their significance is as yet undefined.

Over the past two decades, most efforts were invested in developing strategies for targeting the IGF1R in cancer therapy, sparing the IR, due to concern about metabolic abnormalities secondary to IR inhibition (Judson et al. 1985, Burtrum et al. 2003). However, results from phase 2 and 3 clinical trials indicate that IGF1R inhibition with specific antibodies may result in unacceptable side effects and limited efficacy (Yang \& Yee 2012, Guha 2013). One possible reason for the limited efficacy is that the IR may deliver mitogenic signals independently or as compensation to the IGF1R inhibition. Crosstalk between tyrosine kinase receptors has been shown to confer therapy resistance upon specific targeting of only a single receptor (Engelman et al. 2007). Similarly, enhancement in IR signaling was exhibited following IGF1R downregulation in several breast cancer cell lines (Zhang et al. 2007). Furthermore, IGF2 can drive IR signaling when IGF1R is selectively targeted, which might present another drawback for specific anti-IGF1R targeting (Buck et al. 2010). Thus, determining the role of the IR in breast cancer progression has become highly relevant in the field of oncology.

We have recently demonstrated that dual inhibition of both IR and IGF1R could reduce mammary tumor growth rate (Rostoker et al. 2013). In the current study, we employed short hairpin RNA (shRNA) technology to distinguish between the roles of the IR and IGF1R in mammary tumor growth. We demonstrate the therapeutic efficiency of targeting specific IR in a tumor-specific manner. Moreover, our current results with hyperinsulinemic MKR female mice indicate that, even at high levels, insulin mitogenic signals are mediated mainly through the IR and not through the IGF1R. Microarray analysis identified target genes and alterations in the cancer-associated pathway following IR activation. These results shed light on the effect of IR on cancer progression. Finally, we demonstrate for the first time, to our knowledge, a linkage between the IR and CD24 expression that supports the role of the IR in mammary tumorigenesis.

\section{Materials and methods}

\section{Cell culture}

Mouse mammary cancer cell line, Mvt-1, has been described previously (Pei et al. 2004). Cells were grown in monolayer culture in DMEM (Biological Industries, Beit Haemek, Israel) supplemented with 10\% fetal bovine serum (Biological Industries) and antibiotics (penicillin: streptomycin; Biological Industries) at $37^{\circ} \mathrm{C}$ in a humidified atmosphere consisting of $5 \% \mathrm{CO}_{2}$ and $95 \%$ air.

\section{Animals}

FVB/N and MKR mice (FVB/N background) were used in this study. The generation of the MKR mice, transgenic mice with dominant negative IGF1R specifically targeted to the skeletal muscle, has been described previously (Fernández et al. 2001). Mice were kept on a $12 \mathrm{~h}$ light: $12 \mathrm{~h}$ darkness cycle with access to standard mouse chow and fresh water ad libitum. Mouse studies were performed according to the protocol approved by the Technion Animal Inspection Committee. The Technion holds an NIH animal approval (license number A5026-01).

\section{Knockdown of Igf1r and Ir by lentiviral-based delivery of shRNA}

Vectors (GIPZ) encoding the following microRNA-adapted shRNA 5'-TGACTGTGAAATCTTCGGC-3' (mouse/human IGF1R), 5'-AGACCAGACCCGA AGATTTCT-3' (mouse IR) packed in high-titer lentiviral particles were purchased from Open Biosystems (Huntsville, AL, USA). These vectors or a vector containing a scrambled shRNA sequence (control shRNA; Open Biosystems) were used to infect Mvt- 1 cells in the presence of $8 \mu \mathrm{g} / \mathrm{ml}$ polybrene (Sigma-Aldrich); all three vectors contained a GFP marker and puromycin resistance gene. Stable knockdown (KD) of $I g f 1 r$ and $I r$ was achieved by selection with $2 \mu \mathrm{g} / \mathrm{ml}$

Published by Bioscientifica Ltd. 
puromycin (Sigma-Aldrich). It is important to note that the shRNA platform induces KD of both IR isoforms (IR-A and IR-B), as the shRNA targets the mRNA, from which both isoforms are derived.

\section{In vitro signaling assays}

Cells were washed twice with PBS from their serumsupplemented media, then grown for $16 \mathrm{~h}$ in serumfree media before a 10-min stimulation with insulin (10 nM) or IGF1 (10 nM). For IR blockade, cells were pretreated for $30 \mathrm{~min}$ with $100 \mathrm{nM}$ of the high-affinity IR antagonist S961 (a gift from Novo Nordisk, Maaloev, Denmark).

\section{Syngeneic orthotopic tumor models}

Infected cells (scrambled/Ir-KD/Igf1r-KD Mvt-1 cells) or sorted Mvt-1 cell populations (CD24 ${ }^{-}$and CD24 ${ }^{+}$Mvt-1 cells) were suspended in $100 \mu \mathrm{l}$ PBS and then injected $\left(5 \times 10^{4}\right.$ cells/mouse $)$ into the left inguinal mammary fat pads (\#4) of 8-week-old MKR female mice. Tumor volume was monitored once a week using calipers; the volume was calculated in $\mathrm{mm}^{3}$ by the following formula: (width ${ }^{2} \times$ length $\times 0.5$ ). After killing, tumors were removed and weighed, then flash frozen in liquid nitrogen, and kept at $-80{ }^{\circ} \mathrm{C}$ for further analysis.

\section{Protein extraction and western blot analysis}

Western blot and densitometric analyses were carried out for protein detection in cells and tumor tissues as described previously (Rostoker et al. 2013). The following antibodies were used: phospho-IR $\beta^{\mathrm{Y} 1150 / 51} / \mathrm{IGFIR} \beta^{\mathrm{Y} 1135 / 36}$, IR $\beta$, IGF1R, phospho-Akt ${ }^{(\text {Thr308) }}$, total Akt, phosphop44/42 (Thr202/Tyr204) MAPK, total p44/42-MAPK (Erk1/2), and $\beta$-actin purchased from Cell Signaling Technology (Danvers, MA, USA), followed by a matched secondary antibody conjugated with HRP (Jackson Laboratories, Bar Harbor, ME, USA).

\section{Tail vein metastasis assay}

Ten thousand Mvt-1 cells were injected through the tail vein to assess lung metastatic activity.

Mice were killed 28 days following injection, lungs were removed and fixed in $4 \%$ paraformaldehyde, embedded in paraffin, sectioned, and stained using hematoxylin and eosin (H\&E).

\section{Gene expression array studies}

Mvt-1 cells were starved with a serum-free medium for $16 \mathrm{~h}$ and then treated for 90 min with $10 \mathrm{nM}$ insulin. Total RNA was isolated using the total RNA purification kit (NORGEN Biotek Corp., Thorold, Canada) according to the manufacturer's instructions. RNA was amplified into cRNA and labeled by in vitro transcription using the Illumina TotalPrep RNA Amplification Kit (Ambion, Applied Biosystems, Foster City, CA, USA). Samples were then hybridized to the Mouse WG-6 v2.0 Expression Beadchip according to manufacturer's instructions for the direct hybridization assay (Illumina, Inc., San Diego, CA, USA). Arrays were scanned using the Illumina Bead Array Reader Confocal Scanner. Array data export processing and analyses were performed using the Illumina BeadStudio V.2009.1 Software for extraction and quality control. The raw data obtained were imported into the Eureka-DMA Software and were analyzed as described previously (Abelson 2014). Briefly, filtration of transcripts that were not detected in any sample and expressed at levels below the background intensities was omitted, and differentially expressed genes following insulin treatment were selected using $P$ value $<0.05$ and fold change of at least 1.5. Pathway enrichment analysis was performed with differentially expressed genes $(P$ value $<0.05$ and fold change of at least 1.3) to interrogate molecular pathways enriched upon insulin treatment. The list of genes for the pathway enrichment analysis is provided as Supplementary Table 1 , see section on supplementary data given at the end of this article along with the enriched pathway gene sets (Supplementary Table 2). The data have been deposited in the National Center for Biotechnology Information, and are accessible through GEO Series accession number GSE57139.

In order to also identify molecular and functional interactions between the differentially expressed genes found following insulin treatment, the list of genes was imported into ingenuity pathway analysis (IPA; ingenuity.com). Genetic networks were ranked by score. Scores of 3 or higher have a $99.9 \%$ confidence of not being generated by a random chance alone.

\section{Quantitative PCR for CDNA products}

Quantitative PCR was performed using the Absolute Blue SYBR-Green ROX Mix (Thermo scientific, ABgene, Epsom, UK). RNA was extracted from treated Mvt-1 cells using the Total RNA Purification Kit (NORGEN Biotek Corp.) according to the manufacturer's instructions, followed by singlestranded cDNA synthesis using the Verso reverse transcriptase (Thermo scientific, ABgene). The expression measurement of

Published by Bioscientifica Ltd 
the designated genes was performed using the Rotor-GeneTM 6000 system (Corbett Research, Sydney, NSW, Australia) and its software, version 1.7. The relative gene copy number was normalized using b2 microglobulin (B2m) as an independent internal control gene, and calculated from the threshold cycle $(\mathrm{Ct})$ by the $2^{-\left(C \mathrm{t}_{(n)}-C \mathrm{t}_{\text {(normalizer }}\right)}$ method. The primers used were as follows: $B 2 m$, forward: TTCTGGTGCTTGTCTCACTGA and reverse: CAGTATGTTCGGCTTCCCATTC; Ets2, forward: CCTGTCAATCTTTCATCAGC and reverse: AGTTCTGCAGGTCACATACG; Hebp1, forward: AGTGTGATCCTTGGTGACAGGTG and reverse: GCTGTTGAGAGCCTGAGTTGGT; cyclin D1 (Ccnd1), forward: GCCCGGCTTTGATCTCTGCT and reverse: TGGAGGCT GCAGGACTTTGC.

\section{Flow cytometry}

The following antibodies were used for cell-surface staining of the Mvt-1 cell line, Pacific-Blue-conjugated
anti-CD24, and Alexa Fluor 647 (AF647)-conjugated anti-CD49F (Biolegend, San Diego, CA, USA). 7-Aminoactinomycin D (7-AAD, Biolegend) was used to gate live cells. Cells were stained at a concentration of $5 \times 10^{6}$ cells/ml of FACS buffer (PBS containing $0.1 \%$ BSA) for 20 min on ice in the dark, after which, the cells were washed twice and resuspended in FACS buffer containing 7-AAD. Stained cells were analyzed using the CyAn ADP Instrument (Dako-Cytomation, Glostrup, Denmark) and the FlowJo 7.25 Analysis Software. Flow cytometry-based cell sorting for $\mathrm{CD} 24^{-}$and $\mathrm{CD} 24^{+}$cells was performed using FACSAria (BD Biosciences, San Jose, CA, USA).

\section{Statistical analysis}

All data are expressed as mean \pm s.E.M. The Mann-Whitney $U$ test was used for statistical analysis of unmatched groups; the Wilcoxon's signed-rank test was used for
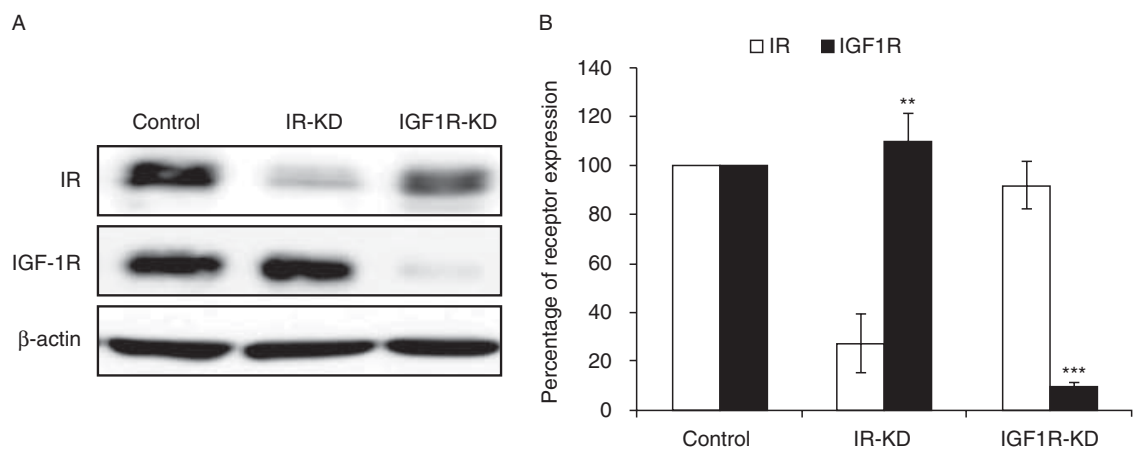

C

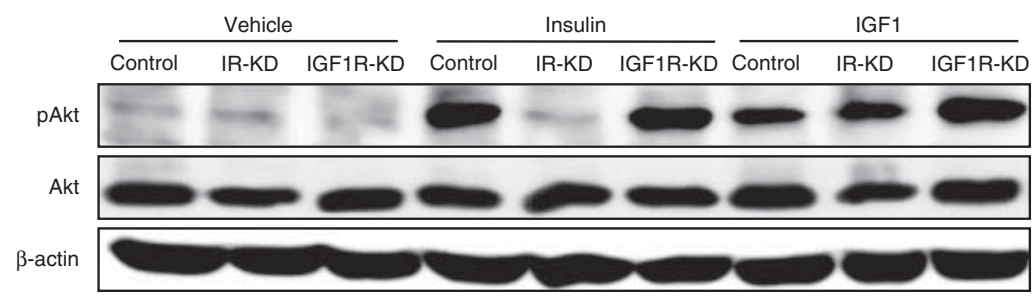

D

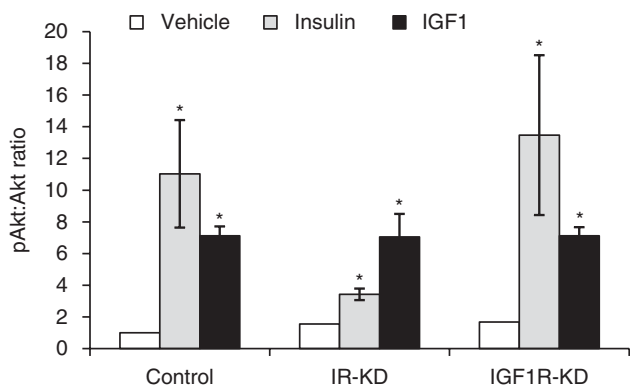

\section{Figure 1}

Ir-KD cells were poorly responsive to insulin, whereas Igf1r-KD cells responded well to IGF1. (A) IR and IGF1R were downregulated in the Mvt-1 cells using shRNA constructs and a non-silencing (scrambled) shRNA construct was used as a control. To confirm KD efficiency, cellular lysates of Mvt-1 cells infected with lentiviral particles containing shRNA sequence against IR, IGF1R, and non-silencing sequence were separated by SDSPAGE, and both IR and IGF1R protein levels were assessed using specific antibodies by western blotting. (B) Protein expression was quantified relative to $\beta$-actin expression by densitometric analysis. (C) Cells were starved with a serum-free medium for $16 \mathrm{~h}$ and then treated for $10 \mathrm{~min}$ with $10 \mathrm{nM}$ insulin or IGF1. Cellular lysates were separated by SDS-PAGE, and expression of pAkt, Akt, and $\beta$-actin was assessed using specific antibodies by western blotting. (D) Protein expression was quantified by densitometric analysis; pAkt levels were normalized to Akt expression and phosphorylation for insulin and IGF1-treated cells was determined. Equal loading of proteins was demonstrated by immunoblotting with an antibody directed against $\beta$-actin. The Mann-Whitney $U$ test was performed to compare the difference from the control cells treated with vehicle, $* P<0.05, * * P<0.005$, and $* * * P<0.001$.

Published by Bioscientifica Ltd. 
matched group comparisons, with $P$ values $<0.05$ considered statistically significant.

\section{Results}

\section{KD of the Ir and Igf1r has different effects on their responses to their cognate ligand}

In order to distinguish between the roles of IR and IGF1R in breast cancer initiation and progression, we used shRNA lentiviral technology to knock down each receptor in the murine mammary Mvt-1 cell line. KD specificity and efficiency for each receptor were confirmed by immunoblotting of whole-cell lysates. Densitometric analysis indicates an approximately $70 \%$ reduction in IR expression in the $I r$-KD cells with no effect on IGF1R expression when compared with control cells that were targeted with a non-targeting scrambled construct. In the Igf $1 r$-KD cells, Igf1r expression was reduced by $90 \%$ following shRNA lentiviral delivery when compared with the control cells (Fig. 1A and B).

Then, we examined the effect of each receptor KD on the functionality of cells. Cells were treated with $10 \mathrm{nM}$ insulin or $10 \mathrm{nM}$ IGF1 for $10 \mathrm{~min}$. The cells were then lysed and phosphorylation of the downstream Akt kinase was measured by western blot analysis. Ir-KD cells displayed a poor response to insulin stimulation when compared with the control cells treated with scrambled siRNA however, they responded well to IGF1, as indicated by Akt phosphorylation levels. The Igf1r-KD cells responded to insulin stimulation in a manner similar to the control cells; however, Akt phosphorylation was also observed in response to IGF1 stimulation (Fig. 1C and D).

\section{Igf1r-KD induces an increased responsiveness of the IR to IGF1 stimulation}

As Akt is activated by IGF1 stimulation in the $I g f 1 r$-KD cells, we postulated that IGF1R downregulation in the cells give rise to highly responsive IR following IGF1 stimulation. To verify this assumption, cells were stimulated with insulin or IGF1, in the presence of the specific IR inhibitor, S961. A significant decrease in Akt phosphorylation level was observed in all three groups of cells when incubated with S961 before insulin stimulation. In the Igf1r-KD cells, S961 pretreatment significantly decreased Akt phosphorylation (47\%) following IGF1 stimulation, an effect that was not observed in both control and $I r$-KD cells (Fig. $2 \mathrm{~A}$ and B). To further demonstrate the sensitivity acquired by IR to IGF1 following Igflr knockdown, we stimulated control and Igf1r-KD cells with a vehicle or IGF1, IR was immunoprecipitated, and phosphotyrosine was examined by western blot analysis. We found that IR was activated following IGF1 stimulation only in the Igf1r-KD cells (data not shown).

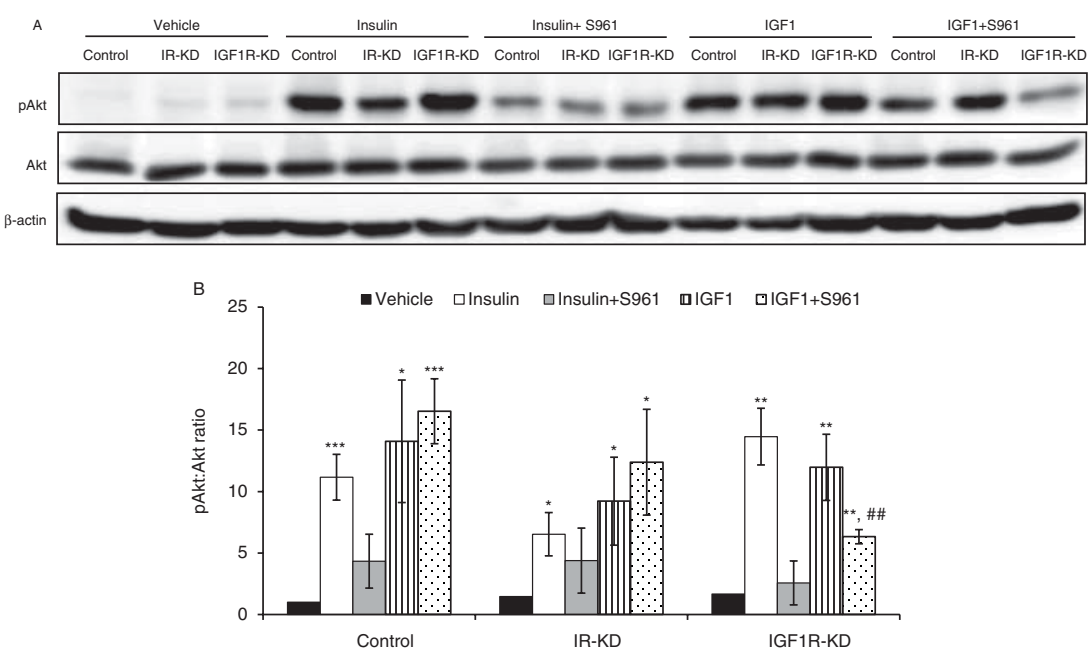

\section{Figure 2}

Severe IGF1R downregulation as accomplished by the shRNA construct results in increased IGF1 response via the IR. Cells were starved with a serum-free medium for $16 \mathrm{~h}$ and then treated for $30 \mathrm{~min}$ with $100 \mathrm{nM}$ of the IR inhibitor $\mathrm{S} 961$ before treatment with $10 \mathrm{nM}$ insulin or IGF1. (A) Cellular lysates were separated by SDS-PAGE, and expression of pAkt, Akt, and $\beta$-actin was assessed using specific antibodies by western blotting. (B) Protein expression was quantified by densitometric analysis; pAkt levels were normalized to Akt expression and relative phosphorylation for insulin and IGF1-treated cells was determined. Equal loading of proteins was demonstrated by immunoblotting with an antibody directed against $\beta$-actin. The Mann-Whitney $U$ test was performed to compare all groups with the control cells treated with a vehicle, ${ }^{*} P<0.05, * * P<0.005$, $* * * P<0.001$, and to compare IGF1 treatment with the IGF1+S961 treatment, ${ }^{\# \#} P<0.005$. 


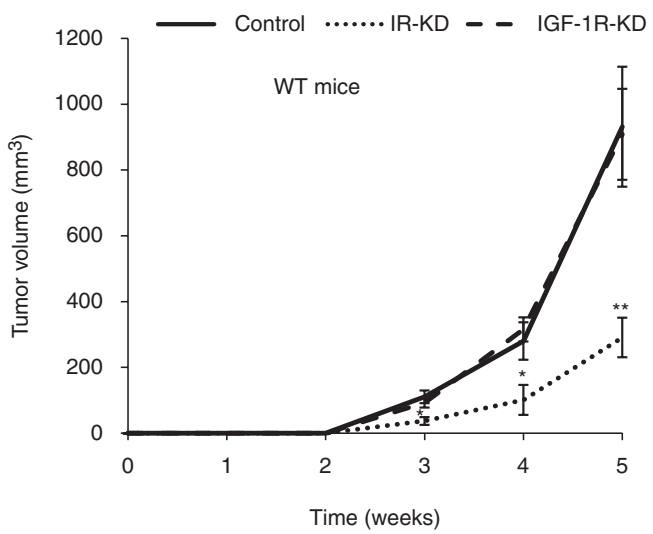

B

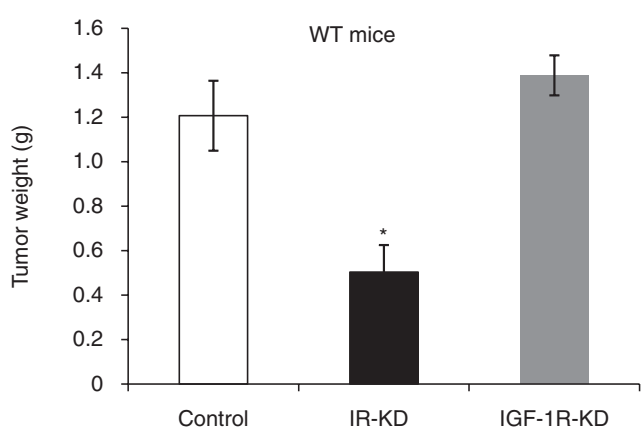

$\mathrm{E}$
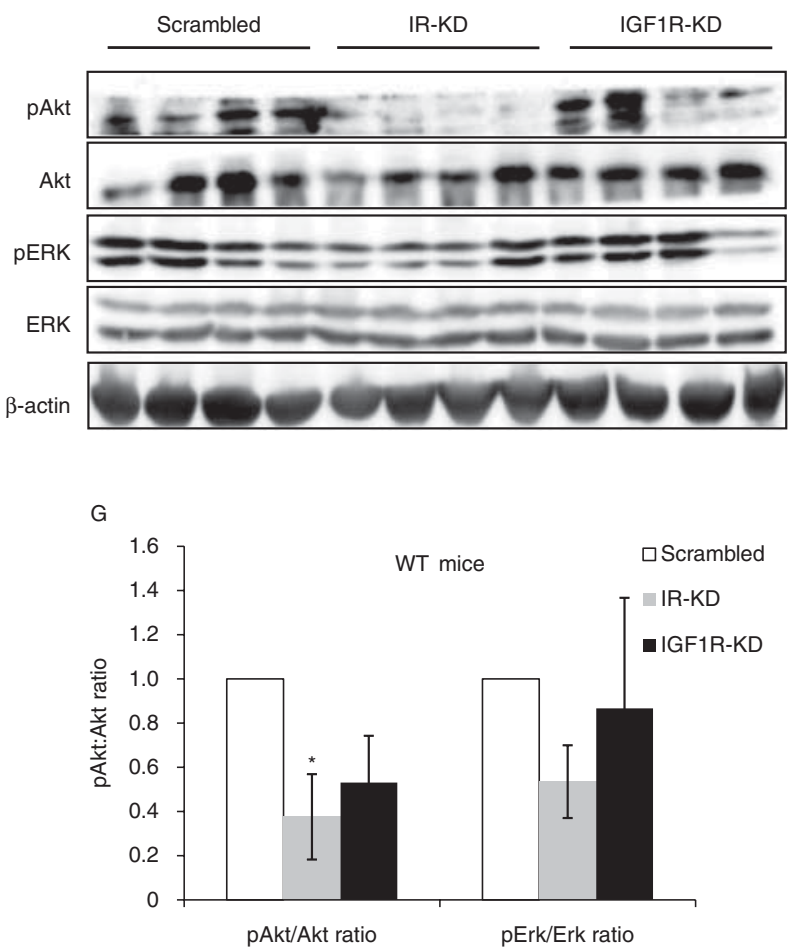

http://erc.endocrinology-journals.org DOI: 10.1530/ERC-14-0490
C

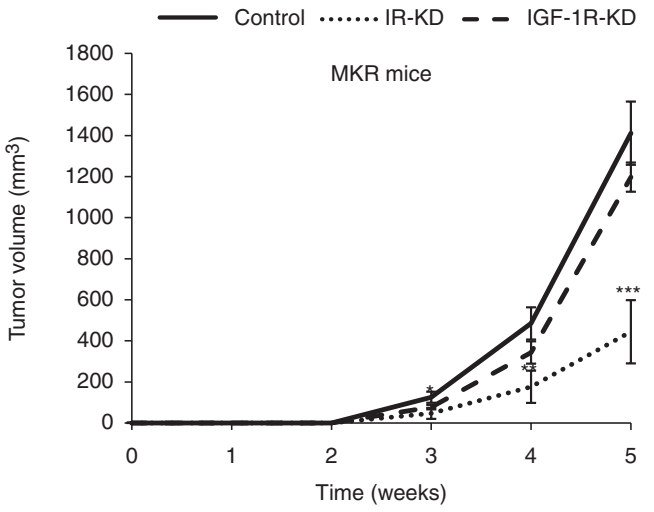

D

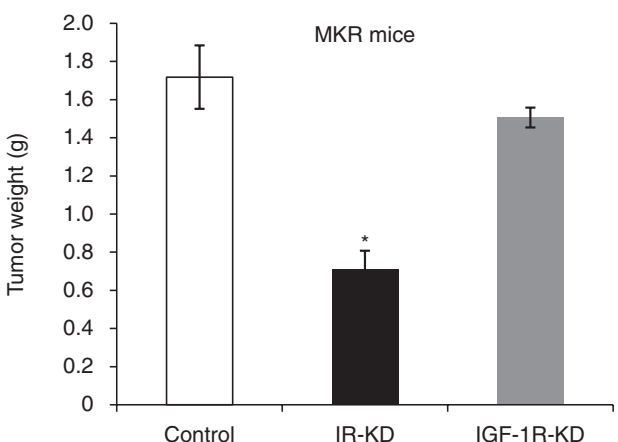

$\mathrm{H}$
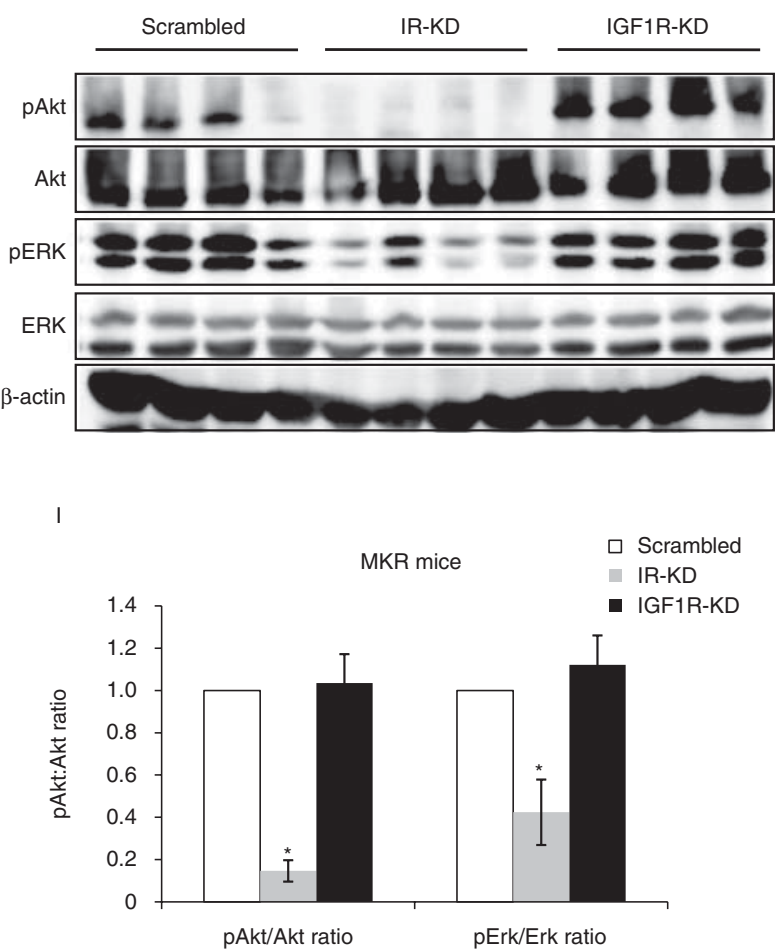


\section{IR plays a significant role in mammary tumor development and metastasis by reducing the activities of both the PI3K/Akt and MAPK pathways}

To evaluate the role of IR and IGF1R in mammary tumor initiation and progression, control cells, $I r$-KD cells, and Igf $1 r$-KD cells were injected into the fourth mammary fat pad of WT and MKR female mice and the tumor volume was measured over the following 5 weeks. The tumor growth rate was significantly reduced in the Ir-KD groups, and at the end of the study, tumor size was reduced in these groups by approximately threefold in both WT female mice and the MKR female mice when compared with the mice that received injections of control cells (Fig. 3A and C). Similar results were obtained for tumor weight, as indicated by the significantly smaller tumors generated following injection of $r r$-KD cells (Fig. $3 \mathrm{~B}$ and D). In contrast, the $I g f 1 r$-KD in the MVT-1 cells did not affect tumor growth in either WT or MKR mice (Fig. 3A, B, C and D). IR and IGF1R intracellular signals are primarily mediated via the PI3K/Akt and the MAPK pathways. In order to determine the activity of both pathways in the mammary tumors generated by the control, $I r-\mathrm{KD}$, and the Igf1r-KD cells in both WT and MKR mice, tumor tissues from the three groups of WT and MKR mice were examined. Western blot analysis revealed a significant decrease in both PI3K/Akt and MAPK pathways in the IrKD-derived tumors compared with the control tumors as shown by a $63 \%$ reduction in Akt phosphorylation level in the WT mice (Fig. 3E and G) and an $85 \%$ reduction in the MKR mice (Fig. 3H and I). Erk1/2 phosphorylation levels were reduced by $47 \%$ in the WT mice (Fig. $3 \mathrm{E}$ and G) and by $67 \%$ in the MKR mice (Fig. $3 \mathrm{H}$ and I). These changes were not observed in the Igf $1 r$-KD-derived tumors. Then, we compared the levels of the metastatic potential (independent of tumor size) of the control, $I r$-KD, and Igf $1 r$-KD cells in both WT and MKR mice. Cells were injected into the tail vein and 28 days following injection mice were killed and lung metastasis was determined by histological analysis. Control cells formed lesions in each of the inoculated WT mice, whereas only $33 \%$ and $50 \%$ of the lungs were found to contain metastases following injection of $I r$-KD and $I g f 1 r$-KD cells respectively (not statistically significant). Similar results were obtained in the MKR mice (Table 1). These results indicate that IR plays a significant role in mammary tumor growth and that both IR and IGF1R mediate metastatic activity.

\section{Gene array analysis reveal alterations in genes and cancer- associated pathways following insulin stimulation}

To evaluate the effect of insulin on the cancer cell transcriptome, we examined gene expression variation along with enriched signaling pathways and gene networks in the Mvt-1 cells following insulin stimulation. In order to identify direct alterations in transcription factors and other primary gene alterations, cells were stimulated for $90 \mathrm{~min}$ with $10 \mathrm{nM}$ insulin. RNA was extracted and subjected to gene expression array studies. A total of 15 genes were found to be differentially expressed (fold change $>1.5$ and $P$ value $<0.05)$ following insulin stimulation as shown in Fig. 4A. Several of the highlighted transcripts have been associated with various processes such as cell growth, migration, and regulation of immune cells. For example, upregulation of the Ets2 transcription factor has been found to be involved in the regulation of the cell cycle and cell transformation (Sementchenko et al. 1998). On the other hand, Hebp1, a transcriptional repressor of several oncogenes, has been demonstrated to be a regulator of cell differentiation that negatively regulates cell proliferation (Sampson et al. 2001). The microarray analysis results indicate a reduction in Hebp1 expression in the Mvt-1 cells following insulin stimulation. In order to reveal the regulation of aberrant pathways, which include genes with a smaller change in expression, appropriate for the 90-min insulin signal induction in this experiment, a cutoff of fold change $>1.3$ and $P<0.05$ were chosen. Pathway enrichment analysis of the differently expressed genes revealed the affiliation of insulin and cancer-associated pathways (Supplementary Table 2) as anticipated. In

\section{Figure 3}

IR plays a significant role in mammary tumor development and metastasis by reducing the activities of both the PI3K/Akt and MAPK pathways. Cells were injected into the fourth mammary fat pad of 8-week-old virgin WT and MKR mice. ( $A$ and C) Tumor volume and ( $B$ and $D$ ) tumor weights were measured at necropsy. (E and $\mathrm{H}$ ) Control, Ir-KD, and Igf1r-KD tumor lysates from WT and MKR mice were separated by SDS-PAGE, and the phosphorylation and protein levels were assessed using specific antibodies by western blotting. ( $G$ and I) Relative expression was quantified by http://erc.endocrinology-journals.org DOI: 10.1530/ERC-14-0490
(C) 2015 Society for Endocrinology Printed in Great Britain densitometric analysis and is presented as a percentage fold change compared with the control group. pAkt levels were normalized to Akt expression, and phospho-ERK1/2 levels were normalized to ERK1/2. Equal loading of proteins was demonstrated by immunoblotting with an antibody directed against $\beta$-actin. The Mann-Whitney $U$ test was performed to compare tumors derived from injected control cells, $* P<0.05, * * P<0.005$, and $* * * P<0.001$

Published by Bioscientifica Ltd. 
Table 1 The number of lungs with lesions out of the total number in the group, following injections of cells into the tail vein

\begin{tabular}{l}
\hline Cell type \\
\hline WT mice \\
Control \\
IR-KD \\
IGF1R-KD \\
MKR mice \\
Control \\
IR-KD \\
IGF1R-KD
\end{tabular}

Metastatic lungs/total lungs

$5 / 5(100 \%)$

$2 / 6(33 \%)$

$3 / 6(50 \%)$

$5 / 6(83 \%)$

$3 / 6(50 \%)$

$4 / 6(66 \%)$

addition to the mTOR and PI3K-Akt signaling pathways, we found that insulin alters several other pathways that are associated with the cell cycle, proliferation, and apoptosis. To validate the microarray results, changes in mRNA levels of two genes, Ets 2 and Hebp1, that regulate the cell cycle and apoptosis were quantified using qRT-PCR in new independent RNA samples. The qRT-PCR results confirmed the microarray data for these three genes, with similar fold changes. Furthermore, we demonstrate that the alterations in expression levels were stable for at least $4 \mathrm{~h}$ for two of these genes (Fig. 4B). Unsurprisingly, we found that IGF1 similarly regulates the same genes (data not shown). To identify gene networks that are active following insulin stimulation, the differentially expressed genes were analyzed using the IPA Software (Ingenuity Systems, Redwood City, CA, USA). Genes were mapped to genetic networks that describe functional relationships, and then the IPA Software was used to associate these networks with known biological pathways. Five networks were found to be significantly altered in the insulin-treated cells, and these networks were associated with cellular growth and development, proliferation, the cell cycle, and immune cell trafficking (Supplementary Table 3, see section on supplementary data given at the end of this article). The top scored network contains genes associated with cellular development, cellular growth and proliferation, and cellular assembly and organization, and this is illustrated in Supplementary Figure 1. This analysis further highlights the mitogenic effects of insulin on cancer cells.

\section{Ir-KD is associated with downregulation of CD24 ${ }^{+}$-expressing cells}

Recently, a subpopulation of breast tumor cells with high tumorigenic capacity have been identified in the MMTVWnt-1 transgenic mice which express CD24 and CD49f, two common cell surface markers for breast cancer stem cells

(Vaillant et al. 2008). It was also demonstrated that CD24 downregulation alters the gene expression pattern and pathways associated with insulin (Sagiv et al. 2008). For this reason, we characterized the cell-surface expression of CD24 and CD49f in the Mvt-1 cells, using flow cytometry analysis. While CD49f expression remained uniform in Mvt- 1 cells, two distinct populations were observed: CD24$(62.4 \%)$ and $\mathrm{CD}_{2} 4^{+}(37.6 \%)$ cells (Fig. 5A) that were separated into pure ( $>98 \%$, as determined by FACS analysis) $\mathrm{CD}_{2}{ }^{-}$and $\mathrm{CD} 24^{+}$cell populations (data not shown). In vitro, both cell populations display a distinct appearance with the $\mathrm{CD} 24^{+}$cells having a slightly more mesenchymal morphology (Fig. 5B). To examine whether IR might be involved in the regulation of CD24 expression, CD24 and CD49f expression was evaluated in the $I r-\mathrm{KD}$ and $I g f 1 r$-KD cells compared with the control cells. FACS analysis revealed a similar percentage of $\mathrm{CD} 24^{-}$and $\mathrm{CD} 24^{+}$subpopulations in both the $I g f 1 r$-KD cells and the control cells; however, a significant reduction (approximately 66\%) in the $\mathrm{CD}_{2} 4^{+}$subpopulation was observed in the $\mathrm{Ir}$-KD cells when compared with the control cells (Fig. 5C).
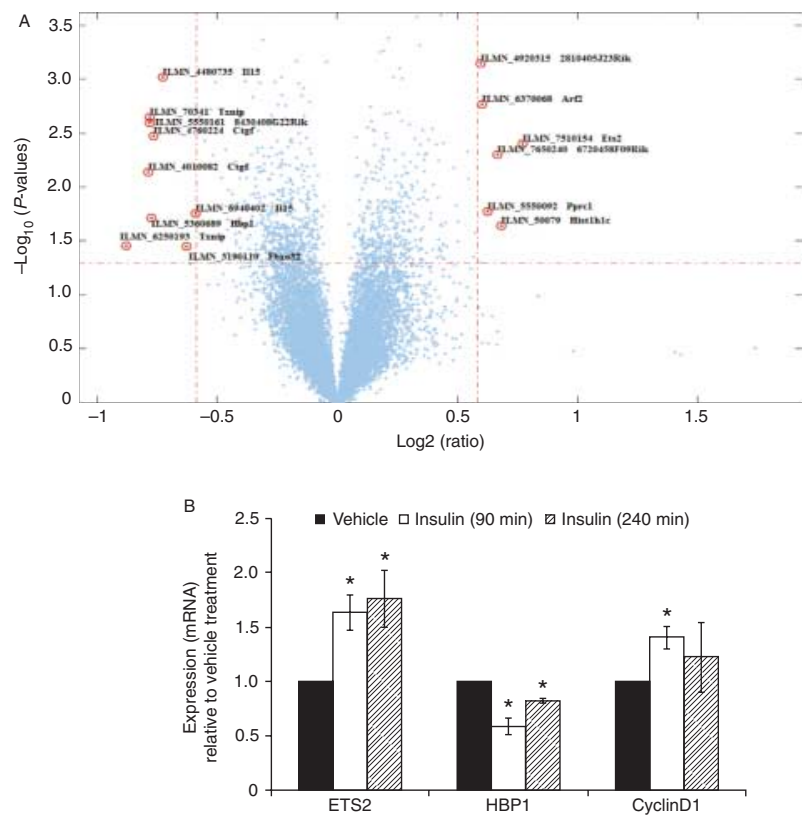

Figure 4

Volcano plot and networks of differently expressed genes following insulin stimulation. Mvt-1 cells were stimulated with insulin (10 nM) for 90 min, RNA was extracted from the vehicle-treated and insulin-treated cells and tested on the Illumina gene-array platform. Volcano plot $(A)$ of $-\log _{10} P$ value vs $\log _{2}$ fold-change shows 15 genes that were differentially expressed by at least 1.5-fold at $P$ value $<0.05$. (B) RNA was extracted from new independent samples of cells stimulated with insulin ( $10 \mathrm{nM}$ and $90 \mathrm{~min})$, and these samples were analyzed using qtPCR. The Mann-Whitney test was performed to compare insulin and vehicle treatments, $* P<0.05$. A full colour version of this figure is available at http://dx.doi.org/10.1530/ERC-14-0490.

Published by Bioscientifica Ltd. 


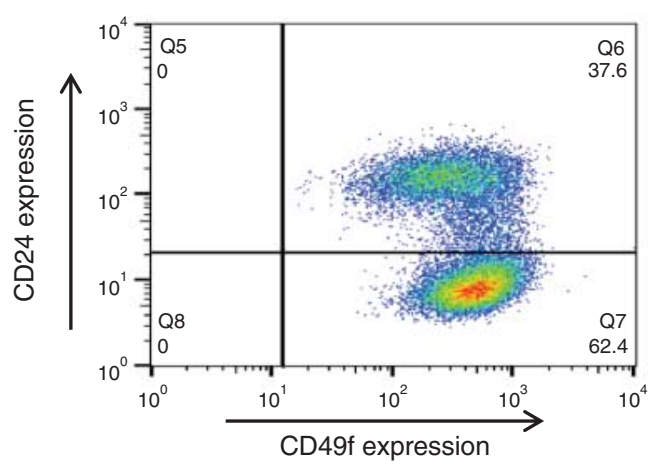

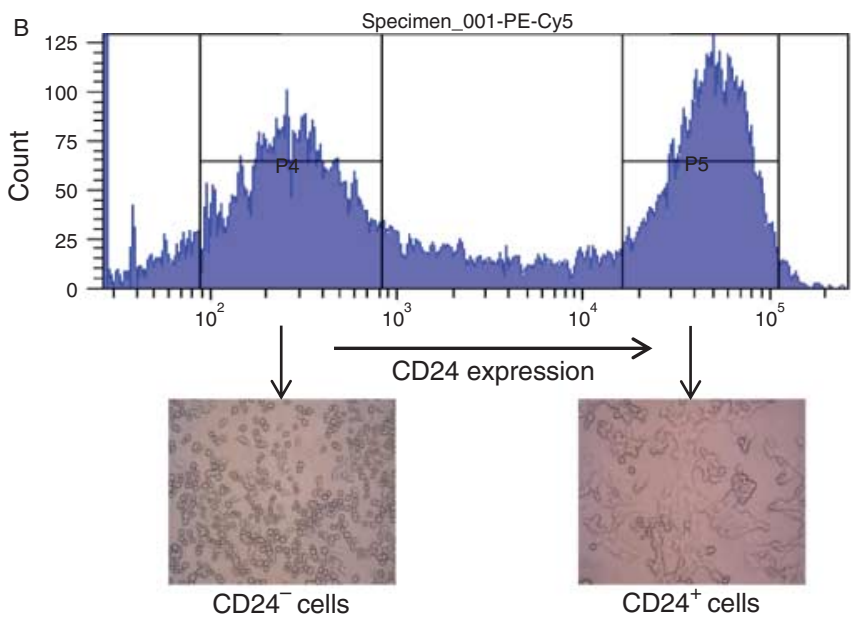

C

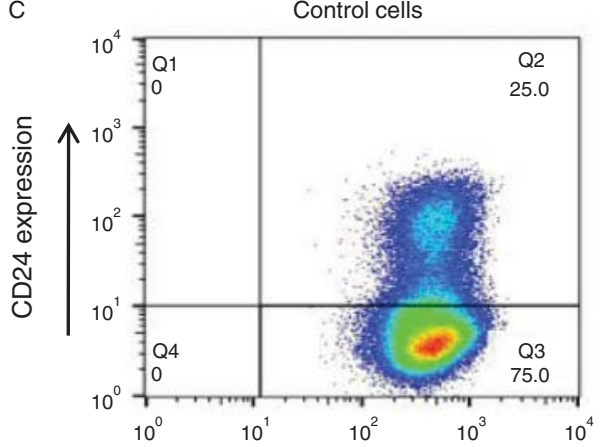

IR-KD cells

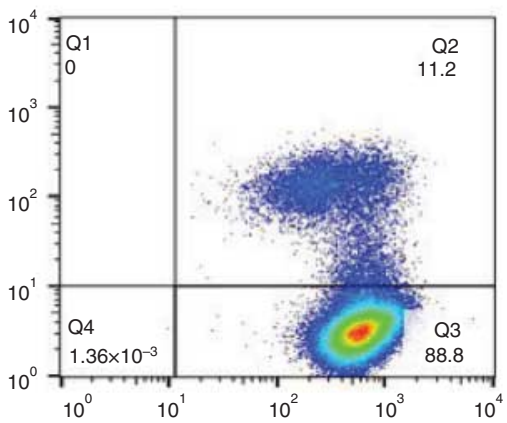

IGF1R-KD cells

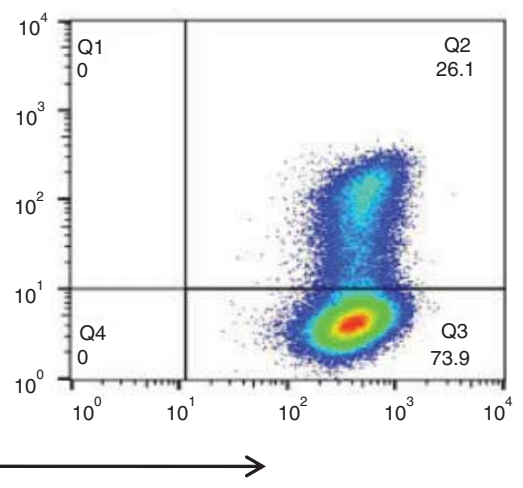

CD49f expression

\section{Figure 5}

Ir-KD is associated with downregulation of $\mathrm{CD} 24^{+}$-expressing cells. (A) A FACS dot plot showing CD24 and CD49f expression in the Mvt-1 cell line. (B) Mvt-1 cells were double sorted into $\mathrm{CD} 24^{-}$and $\mathrm{CD} 24^{+}$cells, and different phenotypes for each group are presented in phase-contrast bright

\section{CD24 expression is associated with partial restoration of tumorigenic capacity of the Ir-KD cells}

CD24 expression has been recently proposed to be a marker for aggressive breast tumors. Based on the observation of reduced tumor size following injection of the $I r$-KD cells, combined with the significant reduction in the $\mathrm{CD}_{2} 4^{+}$cell subpopulation following Ir-KD (in vitro), we examined whether CD24 expression is associated with restoration of the tumorigenic capacity of $I r$-KD cells in vivo. For this purpose, control cells and $I r-\mathrm{KD}$ cells were double sorted into pure (>98\%) CD24- and CD24 ${ }^{+}$cell subpopulations. As shown in Fig. 6, control/CD24 ${ }^{+}$cells generated significantly larger tumors by approximately 2.5-fold when compared with the control/CD24- ${ }^{-}$cells. field images of cells grown in adherent cultures. (C) Representative FACS dot plots of CD24 and CD49f cell surface expression in control, Ir-KD, and Igf1 $r$-KD cells, and $\mathrm{CD} 24^{+}$cells are gated. A full colour version of this figure is available at http://dx.doi.org/10.1530/ERC-14-0490.

Interestingly, CD24 expression in Ir-KD cells was associated with the rescue, at least partially, of tumorigenic capacity; Ir-KD/CD $24^{+}$cells formed significantly (approximately 3.7-fold) larger tumors, when compared with the Ir-KD/CD24- cells (Fig. 6B and C). Moreover, while both tumor volume and tumor weight for the $I r-\mathrm{KD} / \mathrm{CD} 24^{-}$ cells were significantly reduced in comparison to the control/CD24- ${ }^{-}$cells, tumors generated by $I r-\mathrm{KD} / \mathrm{CD} 24^{+}$ cells demonstrated similar weight to tumors generated by the controls/CD24 ${ }^{+}$group. However, the tumor volume was significantly reduced compared with tumors from the control/CD24 ${ }^{+}$group (Fig. 6C and D). These results further support our in vitro observations and indicate that cell-surface expression of CD24 might be related to IR expression and more aggressive tumor growth. 
A

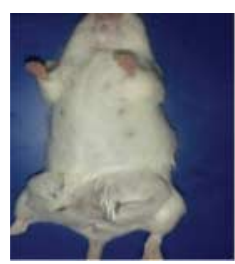

Control (left: CD24-, right: CD24+) IR-KD (left: CD24-, right: CD24+)

B

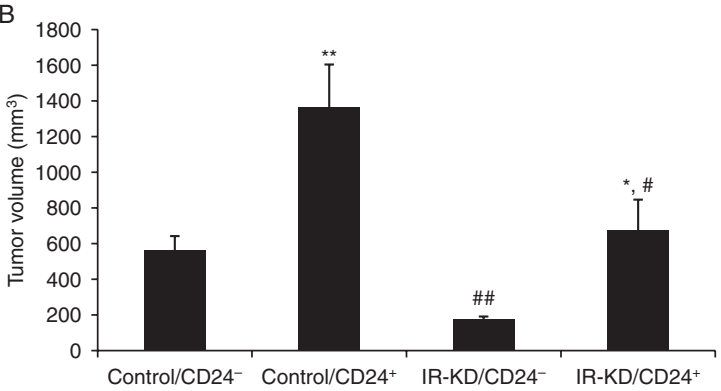

C

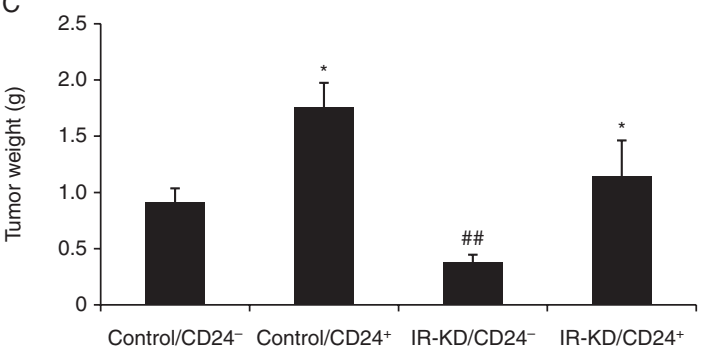

Figure 6

CD24 expression is associated with partially restored tumorigenicity of the Ir-KD cells. Control and Ir-KD cells were double sorted into CD24- ${ }^{-}$and $\mathrm{CD} 24^{+}$cells. Control/CD24- ${ }^{-}$or Ir-KD/CD24- cells were injected into the right mammary fat pads of 8-week-old virgin WT and MKR mice, and the same number of control/CD24 ${ }^{+}$or $/ r-K D / C D 24^{+}$cells were injected into the right mammary fat pad. (A) Mice were killed and tumors were compared between groups. (B) Tumor volume and (C) tumor weight were measured at necropsy. The Wilcoxon's test was performed to compare the difference between tumors derived from control/CD24 ${ }^{-}$and $/ r-\mathrm{KD} / \mathrm{CD} 24^{-}$cells with tumors derived from control/CD24 ${ }^{+}$and $/ r-\mathrm{KD} / \mathrm{CD} 24^{+}$cells, ${ }^{*} P<0.05$ and $* * P<0.005$. The Mann-Whitney $U$ test was performed to compare tumors derived from Ir-KD cells with tumors derived from control cells, ${ }^{\#} P<0.05$ and ${ }^{\# \#} P<0.005$. A full colour version of this figure is available at http://dx. doi.org/10.1530/ERC-14-0490.

\section{Discussion}

IR and IGF1R belong to the same subfamily of receptor tyrosine kinases and they both share similar structures with overlapping functionality (Blakesley et al. 1996, Saltiel \& Kahn 2001). In an attempt to avoid metabolic abnormalities, most therapeutic strategies were aimed towards inhibiting the IGF1R. However, accumulating data from clinical trials raise speculation as to whether the efforts invested in targeting the IGF1/IGF1R axis alone could be fruitful (Yang \& Yee 2012, Guha 2013).
In the current study, we employed shRNA technology in order to discriminate between the roles of IR and IGF1R in tumorigenesis. As expected, we found that $I r$-KD cells are poorly responsive to insulin, but maintain responsiveness to IGF1. Surprisingly, our results indicate that the Igf $1 r$-KD cells remain IGF1-responsive. It has previously been suggested that IR responsiveness may compensate for IGF1R inhibition. Zhang et al. (2007) demonstrated that IGF1R downregulation induces IR hypersensitivity to insulin as a result of an incremental increase in holo-IR formation. On the other hand, it was demonstrated that IGF1R blockade with the specific SCH717454 antibody can be overcome by IGF2-1R crosstalk with the IR (Bid et al. 2012). Using S961, which specifically blocks IR, we confirmed hypersensitivity of the IR not only to insulin but also to IGF1 as a result of $I g f 1 r$ KD. These results, along with the finding that the IMC-A12 antibody (and IGF1R specific antibody) induces IR-IGF1 interaction (Weinstein et al. 2014), indicate that, in order to eliminate the mitogenic signals of IGFs, inhibition of both receptors should be considered.

Previously, it has been demonstrated using the transgenic PyVmT/MKR and rtTA-Neu mice models and the syngeneic Met- 1 and MCNeuA orthotopic mice models that hyperinsulinemia promotes accelerated mammary tumor growth through IR/IGF1R activation. However, there was no discrimination between the two receptor tyrosine kinases (Fierz et al. 2010, Novosyadlyy et al. 2010). In this study, we found that $I r$-KD cells form significantly smaller tumors in both WT and MKR mice compared with the control cells. On the other hand, Igflr-KD had no inhibitory effect on tumor growth, which could be the result of mitogenic signals delivered by both insulin and IGF1 through the IR, as indicated by the in vitro results. Furthermore, the reduction in mammary tumor growth, following injection of $I r$-KD cells into the hyperinsulinemic MKR mice, indicates that the mitogenic signals of insulin are mainly delivered via the IR and not via the IGF1R as proposed previously (Noto et al. 2013). The results of the current study indicate that mammary tumor-specific treatment effectively prevents tumor growth and avoids metabolic abnormalities. Alternatively, both receptors can be inhibited simultaneously to a lesser degree, as we have described previously, thereby reducing tumor burden with minimal metabolic side effects (Rostoker $e$ al. 2013). The PI3K/Akt and the MAPK pathways are the primary signaling cascades for delivering insulin and IGF1 signals. In this study, we demonstrate a dramatic decrease in the activity of the PI3K/Akt pathway and a moderate but

Published by Bioscientifica Ltd. 
significant decrease in the activity of the MAPK pathway in the $I r$-KD-derived mammary tumors.

An additional finding in our study involves the metastatic potential of tumors imparted by the IR and IGF1R. IGF1R has been recently found to mediate the metastatic activity of the MDA-MB-231 human breast carcinoma cells but not their tumorigenicity (Zhang et al. 2013). In this study, we demonstrated that both IR and IGF1R mediate metastasis of Mvt-1 cancer cells to the lungs, while only IR affects primary tumor growth in this study.

Although the effect of insulin on gene expression has been studied on normal cells such as muscle cells and fibroblasts (Dupont et al. 2001, Rome et al. 2003), much remains to be learned about alteration of transcripts in cancer cells. We found that insulin alters the levels of transcripts associated with the cell cycle, proliferation, and apoptosis in Mvt-1 cells. Moreover, several cancer-associated pathways were enriched upon insulin treatment, in addition to altered genetic networks involved in cellular growth and development, proliferation, cell-to-cell signaling, and immune cell interaction.

CD24 is an anchored cell-surface glycoprotein, mainly associated with the progression of invasive tumors through P-selectin binding, which is expressed by activated endothelial cells and platelets (Akashi et al. 1994, Kristiansen et al. 2004, Lim \& Oh 2005). CD24positive cells were found to possess tumor-initiating cell properties in colon, pancreatic, and hepatocellular cancers (Thomas et al. 2012). It is important to note, however, that results from several studies have indicated that human breast cancer cells with stem-cell-like characteristics are CD24-negative (Abraham et al. 2005, Phillips et al. 2006, Wright et al. 2008).

Using FACS analysis, we demonstrated the existence of two distinct and stable $\mathrm{CD}_{2} 4^{-}$and $\mathrm{CD} 24^{+}$ subpopulations. Gene expression analysis of a human colorectal cancer cell line (HT29) revealed that transient CD24 downregulation induces a decrease in genes related to the Ras pathway, and other proteins in its downstream cascade, in addition to genes of the MAPK family and Akt1 (Sagiv et al. 2008). Our results indicating the generation of smaller mammary tumors by $I r$-KD cells and CD24 cells (R Rostoker, S Abelson, K Bitton-Worms, I Genkin, S Ben-Shmuel, M Dakwar, Z S Orr, A Caspi, M Tzukerman and D LeRoith. unpublished observations) along with the similarity in the signaling pathways that both insulin and $\mathrm{CD} 24$ are found to be involved in prompted us to look for a correlation between IR and CD24 expression. FACS analysis revealed a decrease of more than $60 \%$ in CD24 expression in the $I r$-KD cells compared with that in the control cells. These results indicate a possible mechanism for the lower tumorigenic capacity of $I r$-KD cells; however, it is important to note that $\mathrm{CD} 24$ (in the $I r-\mathrm{KD} / \mathrm{CD} 24^{+}$cells) did not rescue the cells' response to insulin in vitro and, on the other hand, insulin treatment for up to 3 weeks had no effect on in vitro expression of $\mathrm{CD} 24$ (data not shown). Lipid rafts are plasma membrane domains that are known to contain many signaling proteins including IR (Vainio et al. 2002). Results from many studies have indicated that lipid rafts are critical for proper insulin activation of both the PI3K/Akt signaling pathway and the MAPK pathway (Bickel 2002). It has been recently suggested that CD24 acts as a gatekeeper for lipid rafts, thereby regulating signaling processes (Pike 2003). It is plausible that CD24 associates with IR in lipid raft domains, which may explain the reduction in CD24 following $I r$-KD.

Then, we examined the hypothesis that the reduction in the high tumorigenic $\mathrm{CD} 24^{+}$subpopulation may explain the low tumorigenic capacity of the $I r$-KD cells. Indeed, using $I r-\mathrm{KD} / \mathrm{CD} 24^{+}$cells, we demonstrated that CD24-expressing cells can partially restore the tumorigenic capacity of $I r$-KD cells.

Taken together, the results of this study indicate a significant role for IR in the progression of mammary tumors, not only through mediating the mitogenic effect of insulin but also by a crosstalk with IGF1. We suggest that both IR and IGF1R should be targeted to achieve the desired inhibitory effect on tumor growth; however, such a strategy should be carried out in parallel with constant monitoring of blood glucose levels. Furthermore, we demonstrate in this study for the first time, to our knowledge, that CD24 expression is linked to IR in mediating mammary tumor growth. This may reveal a novel mechanism for the mitogenic effects of IR; however, further studies are required to explore the relationship between the two. These results indicating an important role for the IR in cancer progression could lead to new targeted therapeutics in women with breast cancer and other cancers that have similarly been shown to be associated with hyperinsulinemia in obesity, prediabetes, and diabetes.

\section{Supplementary data}

This is linked to the online version of the paper at http://dx.doi.org/10.1530/ ERC-14-0490.

\section{Declaration of interest}

The authors declare that there is no conflict of interest that could be perceived as prejudicing the impartiality of the research reported.

Published by Bioscientifica Ltd. 


\section{Funding}

This work was supported by grants from the American Diabetes Association Research (grant number 1-13-BS-108 to D LeRoith), the Diabetes and Metabolism Clinical Research Center of Excellence, the Clinical Research Institute at Rambam (to D LeRoith), the Israel Science Foundation (to D LeRoith), the European Foundation for the Study of Diabetes and Cancer Programme (to D LeRoith), the Chesed Foundation (to D LeRoith) and the National Cancer Institute (NCl) (Grant 2R01CA128799-06A1) (to D LeRoith).

\section{Author contribution statement}

D LeRoith, R Rostoker, and M Tzukerman developed ideas, and edited the manuscript. R Rostoker, S Abelson, K Bitton-Worms, I Genkin, S Ben-Shmuel, M Dakwar, Z S Orr, and A Caspi conducted the experiments. $\mathrm{R}$ Rostoker wrote the manuscript. All authors contributed to the analysis of data.

\section{References}

Abelson S 2014 Eureka-DMA: an easy-to-operate graphical user interface for fast comprehensive investigation and analysis of DNA microarray data. BMC Bioinformatics 15 53. (doi:10.1186/1471-2105-15-53)

Abraham BK, Fritz P, McClellan M, Hauptvogel P, Athelogou M \& Brauch H 2005 Prevalence of $\mathrm{CD} 44^{+} / \mathrm{CD} 24^{-} /$low cells in breast cancer may not be associated with clinical outcome but may favor distant metastasis. Clinical Cancer Research 11 1154-1159.

Akashi T, Shirasawa T \& Hirokawa K 1994 Gene expression of CD24 core polypeptide molecule in normal rat tissues and human tumor cell lines. Virchows Archiv 425 399-406. (doi:10.1007/BF00189578)

Avruch J 1998 Insulin signal transduction through protein kinase cascades. Molecular and Cellular Biochemistry 182 31-48. (doi:10.1023/ A:1006823109415)

Belardi V, Gallagher EJ, Novosyadlyy R \& LeRoith D 2013 Insulin and IGFs in obesity-related breast cancer. Journal of Mammary Gland Biology and Neoplasia 18 277-289. (doi:10.1007/s10911-013-9303-7)

Belfiore A, Frittitta L, Costantino A, Frasca F, Pandini G, Sciacca L, Goldfine I \& Vigneri R 1996 Insulin receptors in breast cancer. Annals of the New York Academy of Sciences 784 173-188. (doi:10.1111/j.1749-6632.1996. tb16235.x)

Belfiore A, Frasca F, Pandini G, Sciacca L \& Vigneri R 2009 Insulin receptor isoforms and insulin receptor/insulin-like growth factor receptor hybrids in physiology and disease. Endocrine Reviews 30 586-623. (doi:10.1210/er.2008-0047)

Bickel PE 2002 Lipid rafts and insulin signaling. American Journal of Physiology. Endocrinology and Metabolism 282 E1-E10.

Bid HK, Zhan J, Phelps DA, Kurmasheva RT \& Houghton PJ 2012 Potent inhibition of angiogenesis by the IGF-1 receptor-targeting antibody SCH717454 is reversed by IGF-2. Molecular Cancer Therapeutics 11 649-659. (doi:10.1158/1535-7163.MCT-11-0575)

Blakesley VA, Scrimgeour A, Esposito D \& Le Roith D 1996 Signaling via the insulin-like growth factor-I receptor: does it differ from insulin receptor signaling? Cytokine \& Growth Factor Reviews 7 153-159. (doi:10.1016/ 1359-6101(96)00015-9)

Buck E, Gokhale PC, Koujak S, Brown E, Eyzaguirre A, Tao N, Lerner L, Chiu MI, Wild R \& Epstein D 2010 Compensatory insulin receptor (IR) activation on inhibition of insulin-like growth factor-1 receptor (IGF-1R): rationale for cotargeting IGF-1R and IR in cancer. Molecular Cancer Therapeutics 9 2652-2664. (doi:10.1158/1535-7163.MCT-10-0318)

Burtrum D, Zhu Z, Lu D, Anderson DM, Prewett M, Pereira DS, Bassi R, Abdullah R, Hooper AT \& Koo H 2003 A fully human monoclonal antibody to the insulin-like growth factor I receptor blocks ligand- dependent signaling and inhibits human tumor growth in vivo. Cancer Research 63 8912-8921.

Dupont J, Khan J, Qu B-H, Metzler P, Helman L \& LeRoith D 2001 Insulin and IGF-1 induce different patterns of gene expression in mouse fibroblast NIH-3T3 cells: identification by cDNA microarray analysis. Endocrinology 142 4969-4975. (doi:10.1210/endo.142.11.8476)

Engelman JA, Zejnullahu K, Mitsudomi T, Song Y, Hyland C, Park JO, Lindeman N, Gale C-M, Zhao X \& Christensen J 2007 MET amplification leads to gefitinib resistance in lung cancer by activating ERBB3 signaling. Science 316 1039-1043. (doi:10.1126/science. 1141478)

Fernández AM, Kim JK, Yakar S, Dupont J, Hernandez-Sanchez C, Castle AL, Filmore J, Shulman GI \& Le Roith D 2001 Functional inactivation of the IGF-I and insulin receptors in skeletal muscle causes type 2 diabetes. Genes and Development 15 1926-1934. (doi:10.1101/gad.908001)

Fierz Y, Novosyadlyy R, Vijayakumar A, Yakar S \& LeRoith D 2010 Mammalian target of rapamycin inhibition abrogates insulin-mediated mammary tumor progression in type 2 diabetes. Endocrine-Related Cancer 17 941-951. (doi:10.1677/ERC-10-0091)

Gallagher EJ \& LeRoith D 2010 The proliferating role of insulin and insulinlike growth factors in cancer. Trends in Endocrinology and Metabolism 21 610-618. (doi:10.1016/j.tem.2010.06.007)

Goodwin PJ, Ennis M, Pritchard KI, Trudeau ME, Koo J, Madarnas Y, Hartwick W, Hoffman B \& Hood N 2002 Fasting insulin and outcome in early-stage breast cancer: results of a prospective cohort study. Journal of Clinical Oncology 20 42-51. (doi:10.1200/JCO.20.1.42)

Guha M 2013 Anticancer IGF1R classes take more knocks. Nature Reviews. Drug Discovery 12 250-250. (doi:10.1038/nrd3992)

Huang J, Morehouse C, Streicher K, Higgs BW, Gao J, Czapiga M, Boutrin A, Zhu W, Brohawn P, Chang Y et al. 2011 Altered expression of insulin receptor isoforms in breast cancer. PLoS ONE 6 e26177. (doi:10.1371/ journal.pone.0026177)

Judson J, Wyk V, Graves DC, Casella SJ \& Jacobs S 1985 Evidence from monoclonal antibody studies that insulin stimulates deoxyribonucleic acid synthesis through the type I somatomedin receptor. Journal of Clinical Endocrinology and Metabolism 61 639-643. (doi:10.1210/jcem-61-4-639)

Kristiansen G, Sammar M \& Altevogt P 2004 Tumour biological aspects of CD24, a mucin-like adhesion molecule. Journal of Molecular Histology 35 255-262. (doi:10.1023/B:HIJO.0000032357.16261.c5)

Lim S-C \& Oh S-H 2005 The role of CD24 in various human epithelial neoplasias. Pathology, Research and Practice 201 479-486. (doi:10.1016/ j.prp.2005.05.004)

Mathieu MC, Clark GM, Allred DC, Goldfine ID \& Vigneri R 1997 Insulin receptor expression and clinical outcome in node-negative breast cancer. Proceedings of the Association of American Physicians 109 565-571.

de la Monte SM \& Wands JR 2005 Review of insulin and insulin-like growth factor expression, signaling, and malfunction in the central nervous system: relevance to Alzheimer's disease. Journal of Alzheimer's Disease $\mathbf{7}$ 45-61.

Noto H, Goto A, Tsujimoto T, Osame K \& Noda M 2013 Latest insights into the risk of cancer in diabetes. Journal of Diabetes Investigation 4 225-232. (doi:10.1111/jdi.12068)

Novosyadlyy R, Lann DE, Vijayakumar A, Rowzee A, Lazzarino DA, Fierz Y, Carboni JM, Gottardis MM, Pennisi PA \& Molinolo AA 2010 Insulinmediated acceleration of breast cancer development and progression in a nonobese model of type 2 diabetes. Cancer Research 70 741-751. (doi:10.1158/0008-5472.CAN-09-2141)

Peairs KS, Barone BB, Snyder CF, Yeh H-C, Stein KB, Derr RL, Brancati FL \& Wolff AC 2011 Diabetes mellitus and breast cancer outcomes: a systematic review and meta-analysis. Journal of Clinical Oncology 29 40-46. (doi:10.1200/JCO.2009.27.3011)

Pei XF, Noble MS, Davoli MA, Rosfjord E, Tilli MT, Furth PA, Russell R, Johnson MD \& Dickson RB 2004 Explant-cell culture of primary mammary tumors from $M M T V-c-M y c$ transgenic mice. In Vitro Cellular \& Developmental Biology. Animal 40 14-21. (doi:10.1290/1543-706X (2004) $40<14$ :ECOPMT > 2.0.CO;2) 
Phillips TM, McBride WH \& Pajonk F 2006 The response of CD24-/low/ $\mathrm{CD} 44^{+}$breast cancer-initiating cells to radiation. Journal of the National Cancer Institute 98 1777-1785. (doi:10.1093/jnci/djj495)

Pike LJ 2003 Lipid rafts: bringing order to chaos. Journal of Lipid Research $\mathbf{4 4}$ 655-667. (doi:10.1194/jlr.R200021-JLR200)

Rome S, Clément K, Rabasa-Lhoret R, Loizon E, Poitou C, Barsh GS, Riou J-P, Laville M \& Vidal H 2003 Microarray profiling of human skeletal muscle reveals that insulin regulates $\sim 800$ genes during a hyperinsulinemic clamp. Journal of Biological Chemistry 278 18063-18068. (doi:10.1074/ jbc.M300293200)

Rostoker R, Bitton-Worms K, Caspi A, Shen-Orr Z \& LeRoith D 2013 Investigating new therapeutic strategies targeting hyperinsulinemia's mitogenic effects in a female mouse breast cancer model. Endocrinology 154 1701-1710. (doi:10.1210/en.2012-2263)

Rowzee AM, Ludwig DL \& Wood TL 2009 Insulin-like growth factor type 1 receptor and insulin receptor isoform expression and signaling in mammary epithelial cells. Endocrinology 150 3611-3619. (doi:10.1210/ en.2008-1473)

Sagiv E, Starr A, Rozovski U, Khosravi R, Altevogt P, Wang T \& Arber N 2008 Targeting CD24 for treatment of colorectal and pancreatic cancer by monoclonal antibodies or small interfering RNA. Cancer Research 68 2803-2812. (doi:10.1158/0008-5472.CAN-07-6463)

Saltiel AR \& Kahn CR 2001 Insulin signalling and the regulation of glucose and lipid metabolism. Nature 414 799-806. (doi:10.1038/414799a)

Sampson EM, Haque ZK, Ku MC, Tevosian SG, Albanese C, Pestell RG, Paulson KE \& Yee AS 2001 Negative regulation of the Wnt- $\beta$-catenin pathway by the transcriptional repressor HBP1. EMBO Journal $\mathbf{2 0}$ 4500-4511. (doi:10.1093/emboj/20.16.4500)

Sementchenko VI, Schweinfest CW, Papas TS \& Watson DK 1998 ETS2 function is required to maintain the transformed state of human prostate cancer cells. Oncogene 17 2883-2888. (doi:10.1038/sj.onc. 1202220)
Thomas S, Harding MA, Smith SC, Overdevest JB, Nitz MD, Frierson HF, Tomlins SA, Kristiansen G \& Theodorescu D 2012 CD24 Is an effector of HIF-1-driven primary tumor growth and metastasis. Cancer Research 72 5600-5612. (doi:10.1158/0008-5472.CAN-11-3666)

Vaillant F, Asselin-Labat M-L, Shackleton M, Forrest NC, Lindeman GJ \& Visvader JE 2008 The mammary progenitor marker CD61/B3 integrin identifies cancer stem cells in mouse models of mammary tumorigenesis. Cancer Research 68 7711-7717. (doi:10.1158/0008-5472. CAN-08-1949)

Vainio S, Heino S, Mansson JE, Fredman P, Kuismanen E, Vaarala O \& Ikonen E 2002 Dynamic association of human insulin receptor with lipid rafts in cells lacking caveolae. EMBO Reports 3 95-100. (doi:10.1093/embo-reports/kvf010)

Weinstein D, Sarfstein R, Laron Z \& Werner H 2014 Insulin receptor compensates for IGF1R inhibition and directly induces mitogenic activity in prostate cancer cells. Endocrine Connections 3 24-35. (doi:10.1530/EC-13-0086)

Wright MH, Calcagno AM, Salcido CD, Carlson MD, Ambudkar SV \& Varticovski L 2008 Brca1 breast tumors contain distinct CD44 ${ }^{+} / \mathrm{CD} 24^{-}$ and $\mathrm{CD} 133^{+}$cells with cancer stem cell characteristics. Breast Cancer Research 10 R10. (doi:10.1186/bcr1855)

Yang Y \& Yee D 2012 Targeting insulin and insulin-like growth factor signaling in breast cancer. Journal of Mammary Gland Biology and Neoplasia 17 251-261. (doi:10.1007/s10911-012-9268-y)

Zhang H, Pelzer AM, Kiang DT \& Yee D 2007 Down-regulation of type I insulin-like growth factor receptor increases sensitivity of breast cancer cells to insulin. Cancer Research 67 391-397. (doi:10.1158/0008-5472. CAN-06-1712)

Zhang XH-F, Jin X, Malladi S, Zou Y, Wen YH, Brogi E, Smid M, Foekens JA \& Massague J 2013 Selection of bone metastasis seeds by mesenchymal signals in the primary tumor stroma. Cell 154 1060-1073. (doi:10.1016/j.cell.2013.07.036)

Received in final form 9 December 2014 Accepted 5 January 2015
(C) 2015 Society for Endocrinology Printed in Great Britain 